\title{
In situ studies of the interface of natural and man-made systems in a metropolitan harbor
}

\author{
B. C. Аввотt, D. F. Soule, M. Oguri and J. D. Soule \\ Allan Hancock Foundation, University of Southern California; \\ Los Angeles, California, USA
}

\begin{abstract}
EXTRAIT: Etude in situ de l'interface entre le milieu naturel et le milieu modifié par l'homme dans un grand port urbain. Les eaux du port de Long-Beach-Los Angeles, dans la baie de San Pedro en Californie, ont été relativement peu étudieés par rapport á celles des autres grands ports urbains dans le monde. L'urgente necessité de réduire la pollution et les besoins opposeés de developpement industriel ont été á l'origine de l'établissement d'un projetpilote de surveillance et de recherches, par la récolte d'echantillons en bateau et in situ et par des études de laboratoire. Les paramètres suivants ont été étudiés: courbes de température, de salinité, de $\mathrm{pH}$, de turbidité; analyse quantitative des métaux rares, (oligo-éléments), des métaux lourds et des matières organiques; mesures de productivité par les méthodes d'assimilation du carbone-14 et par la spectrophotométrie des pigments; des échantillons benthiques, récoltés avec la drague de Campbell et tamisés, ont été identifiés au niveau de l'espèce. Les oeufs, larves, et petits organismes planctoniques qui ne pourraient survivre sur les sédiments pollués ont été récoltés au moyen de cadres-porte-lames suspendus et protégés par un tamis. Le recensement de espèces des poissons et l'éxamen de leur état physiologiques est en cours. L'inventaire des bactéries a été effectué dans les eaux avoisinant le dégorgement des déchets industriels et des égouts, en relation avec les recrudescences périodiques de la reproduction du phytoplancton. L'étude bactériologique des microorganismes de la emarée rouge» et l'étude des effets de chocs thermiques ont été entreprises. Les résultats montrent que la méthode des cadres «porte-lames» apporte sur la nature et la répartition de la faune des informations que ne procurent pas les récoltes en bateau. Les mesures de plancton se sont avéreés les meilleurs indicateurs des effets nocifs á court terme, tandis que les échantillonnages benthiques rendent mieux compte des effets à long terme.
\end{abstract}

\section{INTRODUCTION}

The present Los Angeles-Long Beach harbor area of San Pedro Bay was discovered in 1542 by the Portuguese explorer Juan Rodriguez Cabrillo, but serious thoughts of developing the area were not entertained until just after the American Civil War, when the United States Department of the Army was faced with the task of transporting men and supplies to the Arizona territory. At this time, the harbor area was mostly mudflats and narrow sloughs with the entrance partially blocked by a sand bar, which allowed a scant two foot clearence at low tide. Although the winds are normally westerly or southwesterly, periodic high "Santa Ana" winds from the 
mountains and desert to the northeast forced ships to anchor on the leeward side of one of the offshore islands some 20 miles away. The transfer of cargo to shore was thus difficult.

The first railroad link to the harbor was completed in 1868, and in 1871 the building of a jetty was proposed to connect Rattlesnake Island (now Terminal Island) to Deadman's Island, which no longer exists following harbor development. A timber jetty first constructed was subsequently nearly destroyed by the boring activities of Teredo, or Limnoria, and was later supplanted by a stone barrier. Major development of the present breakwater was undertaken in the first decade of the twentieth century. The completion of the Panama Canal increased West Coast shipping to the point that municipal wharves were constructed in 1914, and by 1923 the harbor became the busiest Pacific Coast port.

The Los Angeles-Long Beach harbor area is an estuary in natural physical configuration (Fig. 1). Dominguez Slough, which enters the harbor to the north and west, and the Los Angeles River, which formerly entered Cerritos Channel to the east, furnished the major freshwater sources. The Southern California climate is arid, with an annual rainfall varying from less than one inch to 13 or more inches, most of which falls in the winter. The harbor is thus not a true estuary in the classical sense, lacking a major, more or less continual, influx of freshwater. Salinity gradients, which are usually so important to estuarine biology, are not present with any consistency.

In 1923, the course of the Los Angeles River was diverted eastward in San Pedro Bay and channelized for flood control, so that the harbor became an intermittent estuary with a high influx of domestic and industrial wastes but with only occasional rainfall drainage. The famous smog is not altogether a recent phenomenon, since early visitors to the Los Angeles Basin named the area "Valley of the Smokes", from fires used by the Indians to drive game, or from lightning strikes in the dry grass and timber lands. With development, however, both water and air pollution became endemic to the area.

The first pollution oriented complaint recorded in Los Angeles Harbor was levied in 1926 and concerned damage by sulfides to various installations in the area. Pollution from both industrial and domestic wastes increased rapidly in later years to become a serious problem. Complicating the tasks of pollution abatement and enforcement is the fact that San Pedro Bay is divided by political lines, not by physical barriers, into Los Angeles and Long Beach Harbors and is thus under the authority of two large, competing municipal harbor departments. Waters adjacent to the east are controlled by Long Beach City, but not by the harbor department. There are also at least sixteen federal, state, and local agencies with varying authorities and jurisdictional commitments in the harbor. Recently, joint efforts have been undertaken to clean up Los Angeles-Long Beach Harbor.

In 1969, due to an edict by the California Water Quality Control Board, the discharge of oil refinery wastes into Dominguez Channel was prohibited. This has been the single most important step toward the clean-up of Los Angeles Harbor. The water and bottom sediment in the inner harbor had become essentially devoid of life; ships would anchor there in order to kill off fouling organisms and thus avoid costly bottom scraping. REISH (1971) reported a significant increase in the number of species in just 
the brief period since the oil companies ceased dumping waste or oxygen depleting chemical fractions and switched to underground sumps for disposal. Accidents still happen at the wells, and bilges are pumped illegally, however. Canneries and dock installations formerly dumped raw, unfiltered wastes directly into harbor waters. This has been halted, but the need for sewer linkups for ships remains.

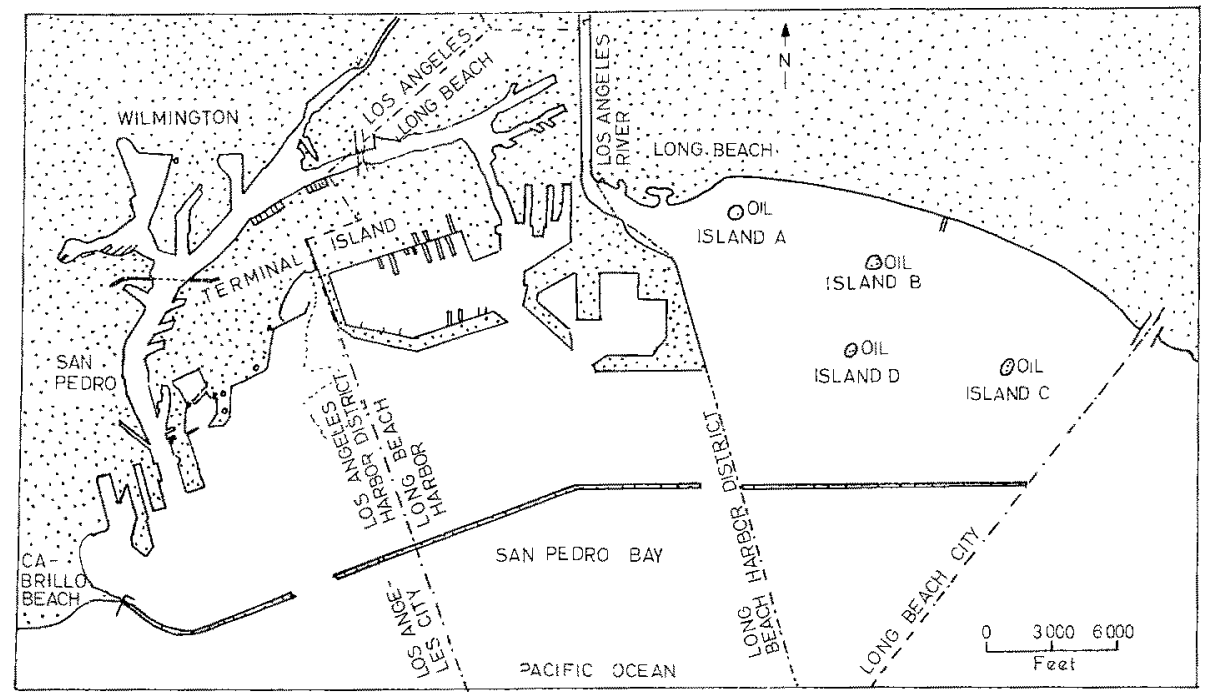

Fig. 1: Area of Los Angeles-Long Beach Harbor

Today, the Harbor system is a focal point for some seven million Southern California residents, and a staging point between all of the United States and the Pacific countries. The third largest port in the United States and growing the most rapidly, the Los Angeles-Long Beach Harbor is not only an active area for drilling and oil refining but has many industries, fish canneries and a large Naval Depot. The beaches lining part of the harbor are popular recreational areas, while the waters are used intensively for recreation boating and for fishing. One of the commercial industries, an anchovy fishery, was so successful that half the annual anchovy haul for the West Coast was made within the outer Harbor in a recent year. Part of the catch is made near the outfalls for filtered cannery wastes and the outfall for primary treated sewage from the surrounding urban area.

Relatively little research has been done in these important harbor area waters, as compared to the waters of older eastern United States Atlantic ports and British or European ports. Over $50 \%$ of the literature dealing with the harbor area has appeared since 1950, at which time the harbor was severely polluted. RersH (1959) mapped the polluted areas. Work by REISH and other scientists from Allan Hancock Foundation at the University of Southern California, in cooperation with the Los Angeles Harbor Department, and studies by the State of California Fish and Game Department have been almost the sole source of information. 
Mounting pressure for pollution abatement has come from federal, state and local sources in keeping with the growing consciousness of environment. Concomitant pressure is, however, being exerted for dredging and development of deeper water port facilities, which makes an intensive, integrated research program an absolute necessity. In 1971, a pilot program of field and laboratory work was initiated by the authors, at the Allan Hancock Foundation. The Office of Sea Grant of the U. S. Department of Commerce has assisted with funding, as have the Los Angeles Harbor Department, the Tuna Research Foundation, and Pacific Lighting Service Company.

\section{TECHNIQUES}

Because of the heavy organic loading of harbor waters by the cannery and sewage outfalls, the visibility in some areas is limited to much less than a meter. The complex bacterial interactions from mixing of these effluents, plus the resulting limited visibility, preclude SCUBA diving technique for baseline inventory and for monitoring. Our personnel are not permitted to dive in some of the Harbor waters at the present time because of the positive readings for coliform bacteria, typhoid and paratyphoid organisms, as well as other as yet unidentified gastroenteritis-causing organisms.

The bottom muds are covered by an unconsolidated, highly organic mud-sludge up to five meters deep in places. In the Fish Harbor area, the bottom "biomass" consists only of blackened fish scales for at least one meter in depth, remains from the days of dumping of unscreened wastes and the flushing of the holds of fishing boats.

Throughout the entire year, the harbor is faced with continuous planktonic pollution. Outfall plumes appear to be transformed into White "Tides" composed of bacteria, colloidal sulphur, and suspended complexes of protein and fat. Green Tides consisting of euglenoids and other species of phytoplankton drift in clouds across the outer harbor at times. In recent years, Red Tides of Gonyaulax polybedra have been found in some parts of the harbor all year long. Coastal Red Tides outside the harbor in the summers sometimes preclude swimming and produce noxious odors, fish kills and shellfish poisoning. Gastroenteritis and occasionally paralysis may result if shellfish which have filtered out large numbers of Red Tide organisms are eaten.

The Hancock Foundation monitoring-research program has been developed as a combination of ship sampling, in situ sampling, and laboratory investigation. Monthly sampling by boat of a series of stations in representative harbor localities is maintained. Physical parameters measured include profiles of temperature, salinity (conductivity), oxygen, $\mathrm{pH}$, turbidity, and major nutrients.

Beginning with the surface biota, metered plankton tows are made, and productivity is measured in terms of carbon 14 incorporation by phytoplankton. A known sample is labelled with radioisotopic carbon dioxide and incubated. The organisms are then filtered off with millipore filters and photosynthetic incorporation is related to chlorophyll content. An unincubated sample is also filtered and the pigment measured by a spectrophotometer.

Benthic samples are taken at the same stations with a stainless steel 0.1 cubic meter 
CAMpBell grab; samples are screened, preserved with formalin-seawater, counted and identified to species.

Because the bottom muds are of very poor quality, if not "dead", in much of the harbor, and because diving is not acceptable as a routine technique, another method, the settling rack, was adopted for assessing the biological quality and content of the waters (SOULE $\&$ SOULE 1971). The rack consists of a series of microscope slides mounted horizontally in a frame suspended from selected buoys at a five meter depth. The frame is covered with a $1.5 \mathrm{~mm}$ mesh plastic screen, so that the slides receive eggs, larvae and small planktonic organisms carried in the water column. Some of these, under less polluted conditions of the bottom substrate, would normally settle out and survive, while others are normally planktonic. Racks are raised monthly, preserved in formalinseawater, and the contents weighed, identified to species and tabulated.

Other studies underway in the harbor focus on bacteriological problems. Cannery and sewer effluents have been injected with rhodamine B dye and marker species of bacteria, and the microbial population traced through arcs of various distances from the sources. Biochemical oxygen demand is also measured.

In the outer harbor, the anchovy, Engraulis mordax, is a major harbor living resource. A study of the free amino-acid pool in muscle tissue of anchovies adjacent to the outfalls as compared with those from waters outside the breakwater is being made. A fish census of numbers, species, physical conditions and pathologies is also being initiated, and the intertidal fauna of the small beach inside the breakwater is being sampled on a grid pattern.

The nutrient outfalls of the canneries and the sewage treatment plant are socially unpopular both in color and odor, but they appear to be very attractive to fish populations, and to citizens who violate harbor regulations in order to fish in these murky waters. It seems possible that complete shut off of these effluents would lower the standing crop of anchovies and other fauna considerably. A managed level of effluent is perhaps beneficial, but more research will be necessary to establish the optimal level. The canneries may actually be forced to shut down before levels can be determined because the oxygen levels of the receiving waters frequently drop below the $5 \mathrm{ppm}$ required by California State Water Quality Board requirements.

Drogue studies were initiated in 1972 in a program to determine harbor circulation patterns, since no comprehensive studies have been done. Cooperating agencies were the Los Angeles Harbor Department, the U. S. Army Corps of Engineers, Long Beach Harbor Department, Pacific Lighting Service Company, Fullerton Junior College, and California State University, Long Beach.

Although extensive organic analysis is at present beyond the financial scope of the projects, some analysis of bottom organics, sediments, trace metals, heavy metals and chlorinated pesticides has been done. In summary, the biology and physical conditions of the stations selected are examined from the surface water, through the water column, to the bottom surface and into the subsurface as completely as possible. 


\section{RESULTS}

Laboratory studies of growth induction of the local Red Tide organism Gonyaulax polybedra have shown that, while all the limiting conditions have not been completely defined, there are trigger factors which initiate rapid multiplication. 'These may be growth hormones or inducers of bacterial origin. Gibberellic acid has been shown to be a growth factor in Gymnodinium breve, the Atlantic coast Red Tide organism (PASTER \& Aввотt 1970). Cultures in the laboratory are maintained axenically and subcultured in sterilized harbor water. Bioassay tests have been inconclusive, suggesting that toxicity of the California Red Tide organism varies. These studies are supported in part by the U.S. Office of Naval Research.

During the past year we have been able to predict the bloom sequences to some extent when effluent loads combine with various sequences of temperature and wind direction. Oxygen levels reach supersaturation (12-16 ppm) as the bloom develops; as the crop dies off, acrobic bacteria begin to multiply, rapidly depleting the oxygen. When oxygen levels drop precipitously, the anaerobic bacteria on the bottom take over, releasing sulphur compounds and damaging boats. We have advised the canneries to stop processing wet fish (non-frozen fish) catches when the oxygen level is supersaturated, in order to prevent the subsequent drop in oxygen below the minimum standard of 5 ppm.

Plankton settling volumes obtained in plankton tows have proven to be good indicators of short-term stress or pollution. In one harbor basin, an empty tow net was reported to the enforcement officer. Subsequent investigation under a dock by a hardhat diver located a leaking chemical pipe. In another instance, seepage from supposedly land-locked oil disposal was revealed. Thus, frequent plankton tows can be of value beyond simple inventory needs.

The settling rack technique has shown that there is a great diversity both of species and of higher categories sampled. Rather surprisingly there was sufficient detritus and debris for 15 species of young polychaetes to begin building tubes on the slides. Also found in the racks were unidentified oligochaetes, polyclad platyhelminths, and copepods, plus two species of coelenterates, one of barnacles, one of tanaids, nine of amphipods, pycnogonids, five species of pelecypods, six species of ectoproct bryozoans, juvenile snails, nudibranchs, and tectibranchs, tunicates, and red and green algae.

Table 1

Biomass values (g) from settling racks at four stations

\begin{tabular}{|ccc|}
\hline Stations & April & September \\
\hline 1 & 60.85 & 123.2 \\
2 & 180.3 & 91.55 \\
3 & 6.95 & 89.70 \\
4 & 10.2 & 220.1 \\
\hline
\end{tabular}

The diversity of settling rack fauna cannot be compared directly with that of benthic samples, since the settling rack represents transient and captive assemblages 
Table 2

Systematic list of settling rack fauna in Los Angeles-Long Beach Harbor

\begin{tabular}{|cc|}
\hline Coelenterates: & Tanaids: \\
Obelia sp. & Anatanais normani \\
Tubularia crocea & Amphipods: \\
Platyhelminthes: & Caprella californica \\
Polyclad flatworm, unidentified & Caprella equilibra \\
Polychaetes: & Caprella verrucosa \\
Anaitides sp. & Caprella sp. \\
Armandia bioculata & Corophinm acherusicum \\
Autolytus sp. & Elasmopus rapax \\
Ctenodrilus serratus & Jassa falcata \\
Eumida sanquinea & Podocerus brasiliensis \\
Exogone sp. & Stenothoe valida \\
Halosydna brevisetosa & Amphipods, juvenile \\
Hydroides pacificus & Pycnogonids: \\
Phyllodocids, juvenile & Unidentified \\
Paleanotus bellis & Pelecypods: \\
Platynereis bicanaliculata & Cbione sp. \\
Polydora limicola & Hiatella arctica \\
Polyophthalmus pictus & Leptopecten latianatus \\
Prionospio cirrifera & Mytilus edulis \\
Opbiodromus pugettensis & Petricola sp. \\
Oligochaetes: & Clams, juvenile \\
Unidentified & Gastropods: \\
Copepods: & Snails, juvenile \\
Harpacticoid copepods, unidentified & Nudibrandos, unidentified \\
Ectoprocts: & Tectibranchs, unidentified \\
Bugula californica & Tunicates: \\
Bugula neritina & Ciona intestinalis \\
Membranipora membranacea & Green algae: \\
Barnacles: & Uloa sp. \\
Balanus amphitrite & Red algae: \\
& Polysipbonia sp. \\
&
\end{tabular}

Table 3

Species diversity of the rack fauna

\begin{tabular}{|crc|}
\hline Stations & April & September \\
\hline 1 & 81 & 132 \\
2 & 53 & 215 \\
3 & 137 & 57 \\
4 & 22 & 129 \\
\hline
\end{tabular}

and shows great seasonal differences. For example, the wet biomass from settling racks at four stations are as presented in Table 1.

The "species diversity" or "bioindex" method of assessing communities, if calculated simply as the number of specimens divided by the number of species, produces some rather inconsistent figures, ranging as listed in Table 3.

Since the racks should not be considered a community, the bioindex should not be interpreted the same way that it might be in assessing stable benthic populations. 
Table 4

Systematic list of benthic samples (Polychaetes) in Los Angeles-Long Beach Harbor

Family Polynoidae

Hesperonoe laevis HartMaN

Polynoid juvenile

Family Polyodontidae Peisidice aspera Jounson

Family Sigalionidae Pboloe glabra HARTMAN

Family Phyllodocidae Anaitides williamsi HaRTMAN Eteone dilatae HARTMAN Eteone sp.

Eumida sanguinea (OERSTED)

Eumida sp.

Phyllodocid, unid. juvenile

Family Hesionidae Ophiodromus pugettensis JoHNSON

Family Pilargiidae Ancistrosyllis iramata Hartman Sigambra bassi Hartman Sigambra tentaculata Treadwell

Family Nereidae Nereidae frag. Nereis procera EhLERs Platynereis bicanaliculata (BAIRD)

Family Nephtyidae Nephtys caecoides HaRTMAN Nephtys californiensis HarTMAN Nephtys cornuta franciscana CLARK. \& JONES Nepbitys ferruginea HaRTMAN

Family Glyceridae Glycera americana LEIDY

Family Goniadidae Glycinde armigera MOORE Goniada brunnea Treadwell

Family Onuphidae Diopatra sp. juvenile Nothria sp. juvenile Onuphid frag.

Family Eunicidae Marphysa disjuncta HARTMAN

Family Lumbrineridae Lumbrineris erecta (MOORE) Lumbrineris minima HARTMAN Lumbrineris sp.

Family Arabellidae Drilonereis falcata MOORE

Family Dorvilleidae Dorvillea articulata (HARTMAN) Dorvelleid frag.

Family Obriniidae Haploscoloplos elongatus JoHNSON Orbiniid frag.
Family Paraonidae Paraonis gracilis oculata Hartman

Family Spionidae Boccardia polybranchia HASWELI Laonice cirrata (SARS) Laonice foliata (MOORE) Polydora bracbycephala Hartman Polydora ligni WeBsTER Polydora limicola ANNENkova Polydora pancil. Polydora socialis (Schmarda) Prionospio malmgreni CLAPAREDE Prionospio pinnata EHLERs Prionospio pygmaeus HartMan

Family Magelonidae Magelona pacifica Monro

Family Chaetopteridae Telepsavus costarum Claparede

Family Cirratulidae Chatozone corona BERKELEY \& BERKELEY

Cirratulids frag. Cirriformia spirobrancha MOORE Tharyx parvus BERKELEY Tharyx sp.

Family Cossuridae Cossura candida HaRTMAN

Family Flabelligeridae Pherusa neopapillata HarTMAN

Family Ophelidae Armandia bioculata HarTMAN

Family Capitellidae Capitella capitata (FABricus) Capitita ambiseta HARTMAN Notomastus (Clistomastus) tenuis MOORE

Family Maldanidae Maldanid frag.

Family Pectinariidae Pectinaria californiensis HARTMAN

Family Ampharetidae Ampbarete labrops HARTMAN Ampharetid frags. Amphisamytha bioculata Moore Melinna oculata Hartman Amplicteis scaphobranchiata MoORE

Family Terebillidae Pista cristata (MmLler) Thelepus setosus (QUATREFRAGEs) Terebellid unid.

Family Sabellidae Chone mollis (BusH) Euchone limnicola REISH Sabellid juvenile 
Benthic sampling at the same stations collected almost entirely polychaetes, with a few pelecypods, amphipods, ophiurids, and nemerteans. There were approximately 60 species of some 30 polychaete families represented in all, taken in the benthic screenings.

\section{CONCLUSIONS}

The broad spectrum monitoring program shows that in situ settling racks offer a means of obtaining information on the quality of the water-column biota not otherwise obtainable by ship sampling techniques. It is most valuable, however, when employed concurrently with physical measurements, and planktonic and benthic sampling. Plankton sampling offers a quick method of discerning short-term trauma, settling racks measure relatively short-term stress, and benthic samples are good indicators of long-term stress.

\section{SUMMARY}

1. The Los Angeles-Long Beach, California, Harbor underwent its first major development early in the twentieth century. It is now the third largest port in the United States, a focal point for seven million southern California residents.

2. Pressures for pollution abatement and for development of a deeper water port make an integrated research program necessary.

3. Allan Hancock Foundation personnel have undertaken a comprehensive study with support from the federal Sea Grant Program, private industry and local harbor departments.

4. Plankton-productivity, marine and public health microbiology, midwater settling rack fauna, benthic fauna, water quality parameters, circulation patterns, and sediment content have been sampled.

5. Sequence of red tide and other phytoplankton blooms have been postulated and predicted.

6. Plankton-settling volumes have been good indicators of short-term stress or pollution.

7. Settling racks suspended monthly have shown a much greater diversity of species and higher categories present in the water column than are present in polluted bottom muds.

8. Some 60 species of 30 polychaete families were taken in bottom samples throughout the harbor.

9. Settling rack sampling measures relatively short-term stress and benthic sampling is a good indicator of longer-term stress.

Acknowledgement. Dr. D. J. ReIsH aided in faunal identifications. 


\section{LITERATURE CITED}

Paster, Z. \& Аввотт, B. C., 1970. Gibberellic acid; a growth factor in the unicellular algae Gymnadinium breqe. Science, N.Y. 169, 600-601.

RersH, D. J., 1959. An ecological study of pollution in Los Angeles-Long Beach Harbors. Occ. Pap. Allan Hancock Fdn. 22, 1-119.

- 1971. The effect of pollution abatement on populations of marine organisms in Los Angeles Harbor, California. Mar. Pollut. Bull. 2, 17-74.

REVIEW of information pertinent to Los Angeles-Long Beach Harbor and Dominguez Channel, 1969. Staff Rep. Los Ang. Reg. Wat. Anal. Bd 1969.

Sovle, D. F. \& Soule, J. D., 1971. Preliminary report on techniques for marine monitoring systems. Sea Grant tech. Note (USC-SG-1T-71), 1-5.

First author's address: Dr. B. C. AввотT

Allan Hancock Foundation

Department of Biological Sciences

University of Southern California

Los Angeles, California 90007

USA 